\title{
PERFORMANCE OF BRAZILIAN AND IMPORTED GLASS IONOMER CEMENTS USED IN ATRAUMATIC RESTORATIVE TREATMENT (ART) REGARDING MICROLEAKAGE IN PRIMARY MOLARS
}

\author{
DESEMPENHO DE CIMENTOS DE IONÔMERO DE VIDRO NACIONAIS E IMPORTADOS \\ UTILIZADOS NO TRATAMENTO RESTAURADOR ATRAUMÁTICO (ART) FRENTE À \\ MICROINFILTRAÇÃO EM MOLARES DECÍDUOS
}

Fernanda de Morais FERREIRA ${ }^{1}$, Miriam Pimenta Parreira do VALE ${ }^{2}$, Wellington Corrêa JANSEN ${ }^{3}$, Saul Martins PAIVA², Isabela Almeida PORDEUS ${ }^{3}$

1- Graduate student (PhD) in the Department of Pediatric Dentistry, Dental School, University of São Paulo (FO-USP), São Paulo, SP, Brazil. 2- DDS, MS, Professor Department of Pediatric Dentistry, Dental School, Federal University of Minas Gerais (FO-UFMG), Belo Horizonte, MG, Brazil.

3- DDS, MS, Professor Department of Operative Dentistry, Dental School, FO-UFMG.

Corresponding address: Fernanda de Morais Ferreira - Rua Aimorés, 2162/ 701, Lourdes, Belo Horizonte, MG, Brazil. CEP.: $30.140-072$. Tel: 5531 3337-7938 - Fax: 5531 3282-9938 - e-mail: fmoraisf@yahoo.com.br

Received: February 10, 2005 - Modification: March 09, 2006 - Accepted: August 28, 2006

\begin{abstract}
W 40 primary molars received two standard class II cavity preparations with margins in enamel. Twenty cavities were filled with Brazilian materials (Vidrion ${ }^{\circledR} \mathrm{R}$ and Vidrion ${ }^{\circledR} \mathrm{R}_{\mathrm{Caps}}$ ) and the other 20 cavities were filled with imported materials (Fuji ${ }^{\circledR}$ IX and Fuji ${ }^{\circledR}$ $\mathrm{IX}_{\mathrm{GPFast}}$ capsule). All fillings were performed by a single operator according to the manufacturer's instructions. Teeth were immersed in $0.5 \%$ methylene blue and half-sectioned. Three independent calibrated examiners assessed microleakage using scores (0-3). Data were submitted to the Kruskal-Wallis statistical test and Wilcoxon analysis. High microleakage indexes were verified for all ionomer cements: $59.5 \%$ of the samples restored with Vidrion ${ }^{\circledR} \mathrm{R}$ or Vidrion ${ }^{\circledR} \mathrm{R}_{\text {Caps }}$ and $83.4 \%$ of the samples restored with Fuji ${ }^{\circledR} \mathrm{IX}$ or Fuji ${ }^{\circledR} \mathrm{IX}_{\mathrm{GPFas}}$ capsule obtained the maximum score (3). The Brazilian ionomer cements presented less microleakage than imported cements, although this difference was only significant $(\mathrm{p}=0.003)$ among the encapsulated materials. Uniterms: Glass ionomer cements; Dental leakage; Deciduous teeth.
\end{abstract}

\footnotetext{
RESUMO

$B$ uscando comparar o desempenho de 2 cimentos de ionômero de vidro (CIV) restauradores convencionais nacionais, mais acessíveis tanto financeiramente quanto por disponibilidade no mercado, ao desempenho de 2 CIV importados frente à microinfiltração, confeccionou-se preparos classe II com término cervical em esmalte em 40 molares decíduos hígidos. Vinte cavidades foram restauradas com os CIV nacionais (Vidrion ${ }^{\circledR} \mathrm{R}$ e Vidrion ${ }^{\circledR} \mathrm{R}_{\text {Caps }}$ ) e as demais com os importados (Fuji ${ }^{\circledR}$ IX e Fuji ${ }^{\circledR}$ $\left.\mathrm{IX}_{\mathrm{GPFas}}\right)$, por um único operador. Os dentes foram impermeabilizados, imersos em azul de metileno 0,5\% e seccionados mesiodistalmente. A microinfiltração foi avaliada por 3 examinadores calibrados, em microscópio estereoscópico, através de escores (0-3). Foram utilizados os testes estatísticos de Kruskall-Wallis e de Wilcoxon. Verificou-se altos índices de microinfiltração para todos os CIV: $59,5 \%$ das amostras restauradas com Vidrion ${ }^{\circledR} \mathrm{R}$ ou Vidrion ${ }^{\circledR} \mathrm{R}_{\text {Caps }}$ e $83,4 \%$ das amostras restauradas com Fuji ${ }^{\circledR}$ IX ou Fuji ${ }^{\circledR} \mathrm{IX}_{\mathrm{GPF} \text { ast }}$ obtiveram o escore máximo (3). Os CIV nacionais apresentaram menos microinfiltração que os CIV importados, embora essa diferença só tenha sido significativa $(p=0,003)$ entre os materiais encapsulados.

Unitermos: Cimentos de ionômero de vidro; Infiltração dentária; Dentes decíduos.
} 


\section{INTRODUCTION}

The search for an ideal restorative material is a challenge for which dentistry has yet to find a solution. Thus, for each individual clinical situation, dentists must consider certain properties in order to identify the most suitable material. Such properties include biocompatibility, adhesion to the dental structure, absence of marginal leakage, wear and pressure resistance, fluoride release, setting time, facilities related to its manipulation and cost.

Glass ionomer cements (GIC) are widely indicated in modern dentistry, especially in atraumatic restorative treatment (ART) and pediatric dentistry. The first commercially produced ionomer had poor esthetic properties, reduced working time and very slow final setting. It therefore received a rather unenthusiastic reaction on the part of clinicians. Interest related to this material later reappeared with improvements to its properties ${ }^{15}$. Other GIC were also introduced to the market, such as silver-modified GIC (Ketac Silver ${ }^{\circledR} /$ ESPE), resin-modified GIC (Vitremer ${ }^{\circledR} /$ $3 \mathrm{M}$ ) and, more recently, conventional GIC with high powder / liquid proportion (Chemflex ${ }^{\circledR} /$ Dentsply, Fuji ${ }^{\circledR}$ IX $_{\mathrm{GP}}$ / GC Corporation, Ketac Molar ${ }^{\circledR} /$ ESPE, Vidrion ${ }^{\circledR} \mathrm{R}_{\text {Caps }}$ / SS White). The latter GIC have improved mechanical properties in comparison with their predecessors ${ }^{21}$ and were especially developed for atraumatic restorative treatment (ART).

ART is a dental care proposal that attempts to control the development of the carious lesion, helping the organism to react against the attack of cariogenic bacteria. It basically consists of partial removal of the carious lesions and subsequent filling of cavities with an adhesive restorative material in association with preventive and educational measures ${ }^{6,7,12}$. Conventional restorative GIC are indicated in ART for their adhesion capacity and fluoride release properties as well as the chemical setting mechanism, which foregoes technological sophistication, as this treatment was initially proposed for places without the proper infrastructure. However, such materials are as yet too costly for widespread use in developing countries such as Brazil, especially those with high powder / liquid proportion ${ }^{18}$. This leads some professionals to look for alternative materials, such as Vidrion ${ }^{\circledR} \mathrm{R}$ (SS White) and even the temporary restorative material IRM ${ }^{\circledR}$ (Dentsply), when performing ART among underprivileged populations, such as those in public institutions.

The aim of the present study was to compare the performance of conventional Brazilian glass ionomer cements, which are considered much more financially accessible and available in the market, to the performance of imported cements suitable for ART with regard to microleakage in class II restorations of primary molars in an in vitro environment.

\section{MATERIALAND METHODS}

The experimental protocol was approved by the Institutional Review Board of the Federal University of
Minas Gerais (report n. 214/01). With the informed consent of children and their families, 40 clinically sound primary second molars were used in the research. Molars had either been extracted for orthodontic reasons or had naturally exfoliated.

Two standard class II cavity preparations were performed on each tooth just above the cementoenamel junction. The cavities were prepared with a 1.8-mm round-tipped cylindrical diamond bur (Microdont 4230) at high-speed under air and water cooling. The bur was replaced after every 5 preparations. Cavity finishing was performed with the same bur at low-speed as well as with manual instruments. The cavity was cylindrical with approximately $2 \mathrm{~mm}$ in diameter and gingival wall situated $1 \mathrm{~mm}$ above the cementoenamel junction.

Restorative procedures were performed by a single operator who did not exceed 3 hours of daily work at $23^{\circ} \mathrm{C}+$ $1-2^{\circ} \mathrm{C}$. The teeth were randomly assigned to two groups of 20 teeth each, according to the GIC mixing method used: hand-mixed or capsulated GIC. Mesial cavities were restored with Brazilian GIC and distal cavities were restored with imported GIC, according to Pin, et al. ${ }^{18}$ (1998), culminating in 4 groups with 20 restorations each:

Group 1 - Vidrion ${ }^{\circledR}$ dentin conditioner was applied to the cavity with a disposable brush for 30 seconds and rinsed 3 times with a moist cotton pellet. Excess water was removed with another cotton pellet. A stainless steel band was adapted to the teeth. The GIC Vidrion ${ }^{\circledR} \mathrm{R}$ was measured, mixed by hand and inserted according to the manufacturer's instructions with the aid of a blunt Hollemback instrument (Duflex).

Group 2 - Application of Fuji ${ }^{\circledR}$ IX liquid to the cavity surface with a disposable brush for 10 seconds, after which the previously described rinsing and drying methods were used. A stainless steel band was adapted to the teeth. The GIC Fuji® IX were measured, mixed by hand and inserted according to the manufacturer's instructions with the aid of a blunt Hollemback instrument (Duflex).

Group 3 - The conditioning procedures and the stainless steel band adaptation were performed in exactly the same manner as in Group 1. The Vidrion ${ }^{\circledR} \mathrm{R}_{\text {Caps }}$ capsule was activated and mixed in agreement with the manufacturer's instructions. The capsule was then opened; the GIC was removed and inserted into the cavity with the aid of a Centrix ${ }^{\circledR}$ syringe.

Group 4 - GC® Cavity Conditioner was applied to the cavity with a disposable brush for 10 seconds, after which the previously described rinsing and drying methods were used. A stainless steel band was adapted to the teeth. The Fuji ${ }^{\circledR} \mathrm{IX}_{\mathrm{GPFas}}$ capsule was activated and mixed in agreement with the manufacturer's instructions. The insertion of GIC into the cavity was performed directly through the capsule adapted to a metallic applicator (GC ${ }^{\circledR}$ Capsule Applier).

The capsulated GIC were mixed using a high-frequency mechanical mixer (CAPMIX® / 3M ESPE). GIC was inserted in the cavities still presenting shine. As soon as the cement began to lose its shiny appearance, pressure was applied for 30 seconds with an amalgam packer (Duflex) lubricated 
with petroleum jelly (Vaseline). Fifteen minutes after the restorative procedure was completed, the band was cut and the restoration was finished using a surgical blade adapted to a scalpel. A layer of varnish was applied (Vidrion ${ }^{\circledR}$ V over mesial restorations and Fuji ${ }^{\circledR}$ Varnish over distal restorations). Specimens were stored in distilled water at $37^{\circ} \mathrm{C}$ for 24 hours and then polished using paper discs (SofLex®/ 3M ESPE). A new layer of varnish was then applied. The materials used to perform the restorations are displayed in Table 1, along with the respective manufacturers, batches, features and mixing methods.

For the microleakage test, the pulp chambers were filled with ultra fast-setting epoxy resin (Araldite $\left.{ }^{\circledR}\right)$ to prevent infiltration of the dye solution. Specimens were then entirely covered with two layers of nail varnish, except for the cervical margin of the class II filling and 1 millimeter beyond it. Next, teeth were immersed in $0.5 \%$ methylene blue water solution ( $\mathrm{pH} \mathrm{7.2}$, at $37^{\circ} \mathrm{C}$ ) for 4 hours, rinsed in tap water, dried for 24 hours and embedded in transparent polyester resin (Crystal).

The specimens were half-sectioned on a precision cutting machine (Isomet ${ }^{\circledR} 1000$ ) with a diamond disk (Buehler ${ }^{\circledR}$ series 15 HC diamond, n. 11.4215) cooled with distilled water. The cut was meant to coincide with the center of the restorations. Nevertheless, anatomical features inherent to deciduous teeth made it impossible to use a single cut in all cases and at times an additional sequential cut was needed. All sections of each restoration obtained after cutting were assessed by three independent calibrated examiners on a stereomicroscope at $30 \mathrm{x}$ magnification to verify dye penetration.

The following criteria based on the work of Yap, et al..$^{30}$ (2000) were used to score the extent of leakage at the cervical margin: 0 = no dye penetration; 1 = dye penetration up to half the extension of the cervical wall; 2 = dye penetration beyond half up to the whole extension of the cervical wall; 3 = dye penetration reaching the axial wall.

Each examiner performed all possible readings for each of the test samples ( 1 test sample $=1,2,3$ or 4 readings, depending on the sections made available by the cuts). The total number of readings amounted to 450 . Median values were used between examiners for each section, as the Kappa test revealed fair agreement among them $(1 \times 2=0.61 ; 1 \times 3=$ $0.71 ; 2 \times 3=0.77)$. Thus, 150 results were obtained for assessment.

The Kruskal-Wallis non-parametric test was applied to compare the median scores of cervical leakage obtained by the three examiners for each of the dental sections $\left(1^{\text {st }}, 2^{\text {nd }}\right.$, $3^{\text {rd }}$, or $4^{\text {th }}$ section obtained by the cuttings) and revealed no differences with regard to the percentage of maximum scores. The Wilcoxon test was used for dependent samples in the comparison of the median scores of microleakage obtained for each material. A significance level of $5 \%$ was considered $(\mathrm{p} \leq 0.05)$.

\section{RESULTS}

Table 2 displays the cervical microleakage scores for each experimental condition. The material with the best performance was Vidrion ${ }^{\circledR} \mathrm{R}_{\text {Caps }}(62.5 \%$ of the samples with light or absence of leakage). The material with the worst performance was Fuji ${ }^{\circledR}$ IX (94.1\% of the samples restored with this material presented severe microleakage).

When the manually mixed and the mechanically mixed correspondents of each GIC were assessed as a group, it was observed (Table 3) that a greater percentage of maximum scores for cervical microleakage was found when using the imported GIC (80.3\%, against 55.4\% when using the Brazilian GIC).

For the Wilcoxon test, an equal number of samples were needed so that $n$ was 21 in all groups. The percentages for the equal samples are not presented due to the similarity obtained between them for the total sample. Table 4 displays the Wilcoxon test results for comparison of microleakage scores for the different GIC. A highly significant difference was observed $(p=0.001)$ in cervical microleakage scores between Brazilian and imported materials, with the former ones presenting smaller values.

When only Fuji ${ }^{\circledR} \mathrm{IX}_{\text {GPFast }}$ capsule and Vidrion ${ }^{\circledR} \mathrm{R}_{\text {Caps }}$ were

TABLE 1- Materials, respective manufacturers, batches, features and mixing methods

\begin{tabular}{|c|c|c|c|c|}
\hline Material & Manufacturer & Batch & Features & Mixing methods \\
\hline \multicolumn{5}{|l|}{ Vidrion $^{\circledR}$ dentin } \\
\hline conditioner & SS White & OOA & Dentin conditioner & \\
\hline Vidrion ${ }^{\circledR} \mathrm{R}$ & SS White & OPU/OPA & Conventional restorative GIC & Manual \\
\hline Vidrion $^{\circledR} \mathrm{R}_{\text {Caps }}$ & SS White & OOE & Conventional restorative GIC & Mechanical \\
\hline Vidrion ${ }^{\circledR} \mathrm{V}$ & SS White & OOE & Protector varnish & \\
\hline \multicolumn{5}{|l|}{ GC ${ }^{\circledR}$ Cavity } \\
\hline Conditioner & GC Corporation & 103221 & Dentin conditioner & \\
\hline Fuji ${ }^{\circledast}$ IX & GC Corporation & 107041 & Conventional restorative GIC & Manual \\
\hline Fuji ${ }^{\circledR}$ IX $X_{\text {GPFASTcapsule }}$ & GC Corporation & 9910263 & Conventional restorative GIC & Mechanical \\
\hline Fuji ${ }^{\circledR}$ Varnish & GC Corporation & 106221 & Protector varnish & \\
\hline
\end{tabular}


compared, the Brazilian material also presented significantly lower $(\mathrm{p}=0.003$ ) cervical microleakage scores than the values presented by the imported material. When assessing only manually mixed GIC, Vidrion ${ }^{\circledR}$ R presented the smallest microleakage scores. However, the difference between these scores could not be considered statistically significant $(\mathrm{p}=0.102)($ Table 4$)$

\section{DISCUSSION}

Assuming the fact that the main intrinsic features of an effective restorative material related to a good marginal sealing are its adhesion capacity to the tooth structure and its dimensional stability, and that conventional GIC present chemical adhesion to the tooth ${ }^{2,13}$, low linear thermal expansion coefficient - similar to the dental structure ${ }^{4,13}$ and minimal setting shrinkage ${ }^{2,24}$, one might expected them to avoid microleakage and all its consequences.

In the present work, however, very high cervical microleakage indices were found for all conventional GIC assessed. From the total sample, $68 \%$ presented a maximum score, $22 \%$ presented some microleakage and only $10 \%$ of samples were leakage-free. The vast majority of papers in

TABLE 2- Microleakage score frequency for each material (median values between examiners)

\begin{tabular}{|c|c|c|c|c|c|c|c|c|}
\hline \multirow[t]{2}{*}{$\begin{array}{l}\text { Microleakage } \\
\text { scores }\end{array}$} & \multicolumn{2}{|c|}{$\begin{array}{l}\text { Vidrion R } \\
\text { (Group 1) }\end{array}$} & \multicolumn{2}{|c|}{$\begin{array}{l}\text { Fuji IX } \\
\text { (Group 2) }\end{array}$} & \multicolumn{2}{|c|}{$\begin{array}{l}\text { Vidrion RCaps } \\
\text { (Group 3) }\end{array}$} & \multicolumn{2}{|c|}{$\begin{array}{c}\text { Fuji IXGPFASTcapsule } \\
\text { (Group 4) }\end{array}$} \\
\hline & $n$ & $\%$ & $n$ & $\%$ & $n$ & $\%$ & $n$ & $\%$ \\
\hline 0 & 0 & - & 1 & 2.9 & 11 & 27.5 & 3 & 7.1 \\
\hline 1 & 4 & 11.8 & 0 & - & 14 & 35.5 & 6 & 14.3 \\
\hline 2 & 1 & 2.9 & 1 & 2.9 & 3 & 7.5 & 4 & 9.5 \\
\hline 3 & 29 & 85.3 & 32 & 94.1 & 12 & 30.0 & 29 & 69.0 \\
\hline Total & 34 & 100.0 & 34 & 100.0 & 40 & 100.0 & 42 & 100.0 \\
\hline
\end{tabular}

TABLE 3- Microleakage score frequency for Brazilian and imported materials (median values between examiners)

\begin{tabular}{|c|c|c|c|c|c|c|}
\hline \multirow[t]{2}{*}{$\begin{array}{l}\text { Microleakage } \\
\text { scores }\end{array}$} & \multicolumn{2}{|c|}{$\begin{array}{c}\text { Brazilian GIC } \\
\text { (Group 1 + Group 3) }\end{array}$} & \multicolumn{2}{|c|}{$\begin{array}{c}\text { Imported GIC } \\
\text { (Group 2 + Group 4) }\end{array}$} & \multicolumn{2}{|c|}{ Total } \\
\hline & $\mathbf{n}$ & $\%$ & $\mathbf{n}$ & $\%$ & $n$ & $\%$ \\
\hline 0 & 11 & 14.9 & 4 & 5.3 & 15 & 10.0 \\
\hline 1 & 18 & 24.3 & 6 & 7.9 & 24 & 16.0 \\
\hline 2 & 4 & 5.4 & 5 & 6.6 & 9 & 6.0 \\
\hline 3 & 41 & 55.4 & 61 & 80.3 & 102 & 68.0 \\
\hline Total & 74 & 100.0 & 76 & 100.0 & 150 & 100.0 \\
\hline
\end{tabular}

TABLE 4- Wilcoxon test results

Lower microleakage

$\begin{array}{llll}\text { Variable } & \text { Compared groups } & \text { p-value }\end{array}$

Brazilian $\mathrm{X}$ imported

Brazilian GIC

(manual mixing)

0.102

(Vidrion R)

Brazilian X imported

Brazilian GIC

Material

(mechanical mixing)

0.003

(Vidrion RCaps)

Brazilian $\mathrm{X}$ imported

Brazilian GIC

(manual and mechanical mixing)

0.001

(Vidrion R / Vidrion RCaps) 
related literature also reveal high cervical leakage indices related to conventional GIC in both permanent ${ }^{1,24,30}$ and deciduous $^{8,28}$ teeth. A few authors, however, have reported considerable marginal sealing with conventional GIC in permanent ${ }^{4}$ and deciduous ${ }^{27}$ teeth. The lack of detailed methodological information makes it hard to conclusively assess the reasons why these authors obtained such good results.

Alperstein, et al. ${ }^{1}$ (1983) and Yap, et al. ${ }^{30}$ (2000) have demonstrated considerable microleakage in GIC restorations even when samples were not submitted to thermocycling, which is known to increase microleakage values. This fact raises the question of what factors other than adhesive capacity and dimensional stability account for adequate initial marginal sealing.

As in vitro assays presented dye penetration in GIC restorations, but the in vivo assays did not detect bacteria under those same restorations, Heys and Fitzgerald ${ }^{10}$ (1991) concluded that either the gap between the dentin and the GIC was too small for the bacteria and their byproducts but big enough to allow dye penetration, or the bacteriostatic / bactericide properties of the material were sufficient in preventing the penetration of viable bacteria. Arcoria, et al. ${ }^{2}$ (1990) have reported that the methylene blue dye molecule is much smaller than $0.5 \mathrm{~mm}$, which would be the space needed to permit the passage of bacteria and their products through the dentin / restoration interface. Therefore, dye penetration is not an absolute indicator of what could take place in a clinical context and thereby overestimates results on many occasions.

Although GIC does not avoid microleakage in the in vitro tooth / restoration interface, the material may present a good performance in clinical situations due to its fluoridereleasing capacity that can postpone or prevent the development of secondary carious lesions, which represent the real clinical threat of microleakage ${ }^{18,28}$. Furthermore, GIC is potentially able to remineralize residual carious dentin to a varying extent in clinical situations such as ART in primary molars ${ }^{25}$. Its preventive role makes GIC widely indicated in pediatric dentistry when the quality of the restoration is often damaged by unsuitable children's behavior. The fact that primary teeth have a limited life span also reduces demands on wear resistance, which remains a setback for $\mathrm{GIC}^{5}$.

Microleakage is a dynamic process that may increase or decrease with time. It is well known that a few clinical events may enhance it (such as successive dimensional changes of the material caused by sudden temperature changes, mechanical occlusal stress and hygroscopic alterations), whereas other events may decrease it (such as the maturation of the restorative material or prolonged exposure to saliva, causing obliteration of the space between the tooth and the restorative material through the deposition of mineral salts) on a long-term basis ${ }^{9}$. A number of strategies can be used to simulate these microleakage events in vitro and, when under a very strict control, may actually mimic what occurs in the mouth. Nevertheless, it was decided not to adopt any of these simulating strategies in the present study. Instead, an attempt was made to control all variables to the utmost for only the appreciation of the initial leakage of different appraised GIC. In future studies, we intend to include other factors that are known to be equally relevant.

As there are reports in the literature that the mixing technique may significantly alter the final properties of the GIC $^{3,11,14,16}$, we chose to work with Brazilian and imported GIC used in ART, which presented a version in separate bottles and an encapsulated correspondent: Vidrion ${ }^{\circledR} \mathrm{R} /$ Vidrion ${ }^{\circledR} \mathrm{R}_{\text {Caps }}$ (commercialized by the Brazilian company SS White) and Fuji ${ }^{\circledR}$ IX / Fuji ${ }^{\circledR}$ IX $_{\text {GPFast }}$ capsule (commercialized by the multinational company GC Corporation).

Brazilian GIC presented a more favorable behavior regarding cervical microleakage than the imported GIC, although this difference was only statistically significant $(p=0.000)$ when the materials were mechanically mixed. Raggio, et al. ${ }^{20}$ (2002) also found smaller microleakage values in Class V restorations performed with Vidrion ${ }^{\circledR} \mathrm{R}$ in relation to Fuji ${ }^{\circledR}$ IX in the cervical wall on deciduous teeth, although this difference was also not statistically significant and the authors only evaluated manually mixed GIC.

The difference between the material setting times may be related to the differences found in microleakage. A very short solidification time may not allow an appropriate flow of GIC to the cavity bottom and may therefore disturb the marginal sealing of the restoration. In the present study, GIC with a shorter setting time presented higher values of microleakage than GIC with a slower setting time (setting time according to the manufacturer's information: Fuji ${ }^{\circledR} \mathrm{IX}=$ 2 min and 20 s; Fuji ${ }^{\circledR} \mathrm{IX}_{\text {GPFast }}$ capsule $=2$ min; Vidrion $^{\circledR} \mathrm{R}=5$ min and $30 \mathrm{~s}$; Vidrion ${ }^{\circledR} \mathrm{R}_{\text {Caps }}=3$ min and $30 \mathrm{~s}$ to 4 min and 30 $\mathrm{s})$. Thus, the reduced setting times of the imported materials, especially the encapsulated form, may have disturbed the appropriate GIC / dental surface adaptation in the cervical area. On the other hand, a slow rate of the GIC setting reaction is one of the problems associated to clinical use ${ }^{11}$. Thus, a reduction in the setting time of conventional GIC is of clinical interest, as the solidification reaction consists of a complex acid / base reaction that is quite sensitive in its initial stage, so that the dehydration or the contamination of the material by humidity during this period can harm the final properties of the GIC ${ }^{11,13}$. This is especially true for ART when it is not possible to use a rubber dam or even saliva suction. Furthermore, a slow setting time may result in lower overall productivity of clinicians, which is undesirable considering the great demand for dental treatment in countries such as Brazil.

Once the form of insertion of two GIC in the cavities was standardized in the most similar way possible for each mixing method, its influence on differences in microleakage was disregarded.

Peutzfeldt and Asmussen ${ }^{17}$ (1990) and Tanumiharja, et al. ${ }^{26}$ (2000) demonstrated that variations in the concentrations and in the time of use of polyacrylic acid do not significantly interfere with the resistance adhesive of conventional GIC to the dentin, and should also not interfere with microleakage. Thus, we disregarded the influence of the different conditioning agents used in the present study 
with respect to microleakage [liquid of the material itself (40\% polyacrylic acid) for Fuji ${ }^{\circledR}$ IX; GC ${ }^{\circledR}$ Cavity Conditioner (20-25\% polyacrylic acid) for Fuji ${ }^{\circledR}$ IX $_{\text {GPFast }}$ capsule; Vidrion ${ }^{\circledR}$ dentin conditioner (11.5\% polyacrylic acid) for Vidrion ${ }^{\circledR} \mathrm{R}$ and Vidrion ${ }^{\circledR} \mathrm{R}_{\text {Caps }}$ ] as well as the different conditioning times employed in accordance with the respective manufacturer's instructions.

Considering mechanically mixed GIC, a possible explanation for the difference in microleakage may be related to differences between the capsules of the two materials with regard to shape, weight, size and location of the sealing wax that separates the liquid from the powder. These factors may influence the effective contact between powder and liquid, as well as the extension of the mixture and, consequently, the powder / liquid proportion in the final material ${ }^{11,14}$. According to Rupp, et al. ${ }^{21}$ (1996), achievement of an appropriate manipulation of encapsulated GIC depends on the correct use of the mechanical mixer. The mixer speed varies due to a number of factors, including the capsule weight. However, more studies are necessary to permit conclusions related to the influence of capsule variations on GIC properties, including microleakage.

In the present study, mesial cavities were restored with Brazilian GIC and distal cavities were restored with imported GIC, according to Pin, et al. ${ }^{18}$ (1998). We do not believe that this option had any effect on the results since no differences regarding the direction of enamel prisms at cervical margins, thickness of enamel, aprismatic layer or dentinal tubular pattern have been observed in the related literature between mesial and distal surfaces of second primary molars ${ }^{22}$.

Well-adapted restorations with adequate marginal sealing are of extreme importance for the success of atraumatic restorative treatment, as isolating the external media is necessary in order to create the proper conditions for the organism to fight the remaining bacterial infection in the dentinal tissue at the bottom of the cavity, and also to remineralize the local dental structure ${ }^{26}$.

An interesting result originated from the comparison between GIC: a better performance was expected from the imported materials to which improved properties are attributed than the other conventional restorative GIC due to the high powder / liquid proportion ${ }^{23,29}$. Nonetheless, a favorable result was observed with Vidrion ${ }^{\circledR} \mathrm{R}$ and Vidrion ${ }^{\circledR}$ $\mathrm{R}_{\text {Caps }}$. This seems very appropriate, since they are much more financially accessible products than Fuji ${ }^{\circledR}$ IX or Fuji ${ }^{\circledR}$ $\mathrm{IX}_{\mathrm{GPFast}}$ capsule, allowing their wide use in public health both for ART applications and conventional restorative treatment. However, it is important to keep in mind that the present study only assessed microleakage. Other characteristics that were not evaluated here, such as bond strength, fluoride release, solubility, compressive strength, surface hardness, tensile strength, wear resistance, porosity, fracture resistance, setting time and practicability are of extreme importance to the clinical success of glass ionomer cements. Based on such factors, there may be benefits in using one of the imported materials. According to Raggio, et al. ${ }^{20}$ (2002), although the Brazilian GIC are cheaper, they could present some disadvantages, such as a long setting time, accentuated wear and greater solubility over time, so that the final treatment cost may increase if there is need for further intervention.

Despite the many limitations presented by the in vitro studies failing to precisely reproduce clinical conditions, they are still considered very useful for indicating directions in the properties of new materials ${ }^{18}$. However, attention should be drawn to the fact that laboratory studies with small sample sizes in carefully controlled and standardized environments, such as the conditions reproduced in this paper, should not be extrapolated to more complex clinical situations. This makes it of paramount importance to pursue further clinical studies in order to compare in vitro test results with the clinical performance of materials.

\section{CONCLUSIONS}

None of the conventional restoring GIC for atraumatic restorative treatment assessed in the present work was able to avoid the cervical microleakage in class II restorations of primary molars in an in vitro environment, and all presented high indices of dye penetration in the tooth / restoration interface.

Brazilian GIC (Vidrion ${ }^{\circledR} \mathrm{R} /$ Vidrion ${ }^{\circledR} \mathrm{R}_{\text {Caps }}$ ) presented a better performance regarding cervical microleakage in comparison to imported GIC (Fuji ${ }^{\circledR} \mathrm{IX} / \mathrm{Fuji}^{\circledR} \mathrm{IX}_{\mathrm{GPFast}}$ capsule).

Considering the microleakage alone, it appears viable to use GIC Vidrion ${ }^{\circledR} \mathrm{R} /$ Vidrion ${ }^{\circledR} \mathrm{R}_{\text {Caps }}$ as an alternative material in atraumatic restorative treatment.

\section{ACKNOWLEDGMENT}

The authors would like to thank Leandro Medeiros for his cooperation in this study.

\section{REFERENCES}

1- Alperstein KS, Graver HT, Herold RC. Marginal leakage of glassionomer cement restorations. J Prosthet Dent. 1983;50(5):803-7.

2- Arcoria CJ, Vitasek BA, De Wald JP, Wagner MJ. Microleakage in restorations with glass ionomer liners after thermocycling. J Dent. 1990;18(2):107-12.

3- Brooks ES, Miller BH, Nakajima H, Guo I. Manipulation effects on fluoride release from chemically-cured and resin-modified glass ionomers. Am J Dent. 1997;10(3):120-2.

4- Bullard RH, Leinfelder KF, Russell CM. Effect of coefficient of thermal expansion on microleakage. J Am Dent Assoc. 1988;116(7):871-4.

5- Espelid I, Tveit AB, Tornes H, Alvheim H. Clinical behaviour of glass ionomer restorations in primary teeth. J Dent.1999;27:43742.

6- Frencken JE, Holmgren CJ. How effective is ART in the management of dental caries? Community Dent Oral Epidemiol. 1999;27:423-30. 
7- Frencken JE, Makoni F, Sithole WD. ART restorations and glass ionomer sealants in Zimbabwe: survival after 3 years. Community Dent Oral Epidemiol. 1998;26:372-81.

8- Fuks AB, Holan G, Simon H, Lewinstein I. Microleakage of class 2 glass-ionomer-silver restorations in primary molars. Oper Dent. 1992;17(2):62-9.

9- Going RE. Microleakage around dental restorations: a summarizing review. J Am Dent Assoc. 1972;84(6):1349-57.

10- Heys RJ, Fitzgerald M. Microleakage of three cement bases. J Dent Res. 1991;70(1):55-8.

11- Kilpatrick NM, McCabe JF, Murray JJ. Factors that influence the setting characteristics of encapsulated glass ionomer cements. J Dent. 1994;22(3):182-7.

12- Lo ECM, Holmgren CJ. Provision of atraumatic restorative treatment (ART) in restorations to Chinese pre-school children - a 30 month evaluation. Int J Paediatr Dent. 2001;11:3-10.

13- McLean JW, Wilson AD. The clinical development of glassionomer cements: Formulation and properties. Aust Dent J. 1977;22(1):31-6.

14- Mitchell CA, Orr JF, Russell MD. Capsulated versus hand-mixed glass-ionomer luting cements for post retention. J Dent. 1998;26(1):47-51.

15- Navarro MFL, Pascolatto RC. Cimentos de Ionômero de Vidro. São Paulo: Artes Médicas; 1998. (Série EAP-APCD).

16- Nomoto R, McCabe JF. Effect of mixing methods on the compressive strength of glass ionomer cements. J Dent. 2001;29(3):205-10.

17- Peutzfeldt A, Asmussen E. Effect of polyacrylic acid treatment of dentin on adhesion of glass ionomer cement. ACTA Odontol Scand. 1990;48(5):337-41.

18- Pin MLG, Abdo RCC, Machado MAAM, Pavarini A. Avaliação da microinfiltração marginal em cavidades classe II modificadas, restauradas com cimentos de ionômero de vidro, convencional, modificados por resina e com um a resina composta modificada por poliácidos: estudo in vitro. Rev Fac Odontol Bauru. 1998;6(4):1-6.

19- Puddhiarant P, Rapp R. Radiographic anatomy of pulpal chambers of primary molars. Pediatr Dent. 1983;5(1):25-9.

20- Raggio DP, Rocha RO, Imparato JCP. Avaliação da microinfiltração de cinco cimentos de ionômero de vidro utilizados no tratamento restaurador atraumático (TRA). J Bras Odontopediatr Odontol Bebê. 2002;5(27):370-7.

21- Rupp DC, Hermesch CB, Charlton DG. Effect of triturator speed variation on physical properties of encapsulated glass-ionomer luting cements. Oper Dent. 1996;21(3):96-102.

22- Ruschel HC, Chevitarese O. Density and diameter of dentinal tubes of first and second primary human molars - comparative scanning electron microscopy study. J Clin Pediatr Dent. 2002;26 (3):297-304.

23- Rutar J, McAllan L, Tyas MJ. Clinical evaluation of glass ionomer cement in primary molars. Pediatr Dent. 2000;22(6):486-8.

24- Scherer W, Kaim J, Gottlieb-Schein E, Roffe-Bauer M. Microleakage of capsulated glass ionomer cements. Am J Dent. 1989;2(6):355-7.
25- Sepet E, Aytepe Z, Guven Y. Artificially formed caries-like lesions around Class II glass ionomer restorations in primary molars. J Clin Pediatr Dent. 1995;20(1):37-40.

26- Smales RJ, Ngo HC, Yip KH-K, Yu C. Clinical effects of glass ionomer restorations on residual carious dentin in primary molars. Am J Dent. 2005;18(3):188-93.

27- Tanumiharja M, Burrow MF, Tyas MJ. Microtensile bond strenghts of glass ionomer (polyalkenoate) cements to dentine using four conditioners. J Dent. 2000;28(5):361-6.

28- Triadan H. When is microleakage a real clinical problem? Oper Dent. 1987;12(4):153-7.

29- Virmani S, Tandon S, Rao N. Cuspal fracture resistence and microleakage of glass ionomer cements in primary molars. J Clin Pediatr Dent. 1997;22(1):55-8.

30- Yap AUJ, Tan S, Teh TY. The effect of polishing systems on microleakage of tooth coloured restoratives: Part 1. Conventional and resin-modified glass-ionomer cements. J Oral Rehabil. 2000;27(2):117-23. 